\title{
Effect of Sulphur Levels on Yield and Yield Attributes in Intercropping System of Castor along with Mungbean
}

\author{
Y.K. Ghilotia*, R.N. Meena, R.K. Singh, Ajeet Singh and Kailash Verma \\ Department of Agronomy, I.Ag.Sc., B.H.U. Varanasi (UP)-221005 \\ *Corresponding author
}

A B S T R A C T

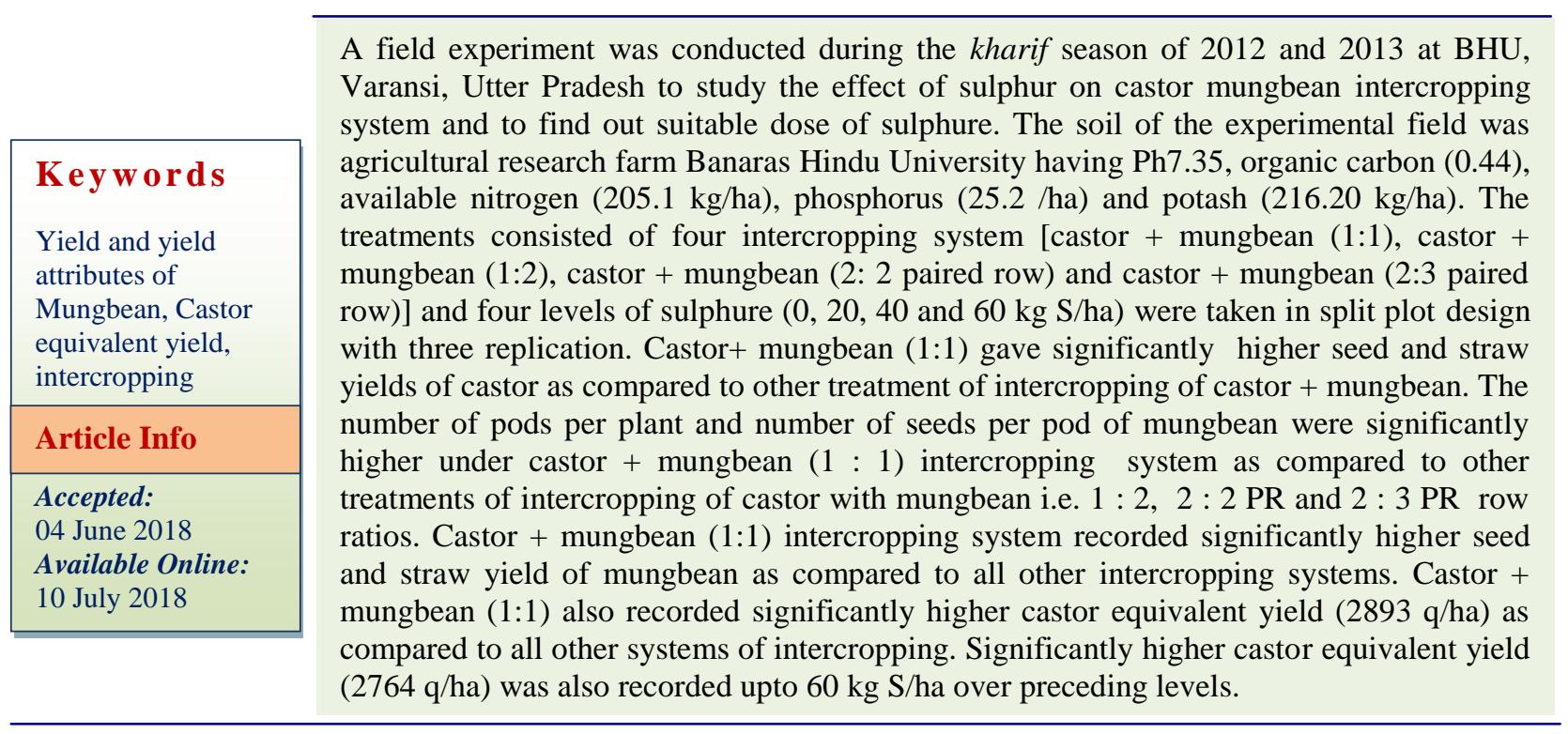

\section{Introduction}

Pulses are the main source of protein particularly for vegetarians and contribute about 14 per cent of the total protein of an average Indian diet. Production of pulses is far below the requirement to meet even the minimum level of per capita consumption. The per capita availability of pulses has been declined from $74.9 \mathrm{~g}$ in 1959 to $33 \mathrm{~g}$ in 2008 as against the minimum requirement of $70 \mathrm{~g}$ per capita/day prescribed by ICMR which causes malnutrition among the growing population (Anonymous, 2007). Therefore, it is necessary that agricultural scientists should evolve the strategy of increasing the production of pulses to meet the protein requirement of increasing population of the country. Mungbean [Vigna radiata (L.)Wilczek] is primarily rainy season crop 
but with the development of early maturing varieties, it has also proved to be an ideal crop for spring and summer season. Mungbean is excellent source of protein $(24.5 \%)$ with high quality of lysine $(460 \mathrm{mg} / \mathrm{g} \mathrm{N})$ and tryptophan $(60 \mathrm{mg} / \mathrm{g} \mathrm{N})$. It also has remarkable quantity of ascorbic acid when sprouted also bear riboflavin $(0.21 \mathrm{mg} / 100 \mathrm{~g})$ and minerals $(3.84$ $\mathrm{g} / 100 \mathrm{~g}$ ) (Gopalan et al., 1995). Mungbean being a leguminous crop, has the capacity to fix atmospheric nitrogen through biological nitrogen fixation. Being a short duration crop it suits well in various multiple and intercroppings system. After picking of pods, mungbean plants may be used as fodder or green manure. Total area under pulses is 24 million hectares with an annual production of 15.19 million tonnes in the country with productivity of $658 \mathrm{~kg} / \mathrm{ha}$ (Anonymous, 2008). In India, mungbean occupies 3.0 million hectares and contributes 1.3 million tonnes in pulse production (Anonymous, 2006). The important mungbean growing states are Orissa, Maharastra, Andhra Pradesh, Tamil Nadu, Uttar Pradesh, Madhya Pradesh, Rajasthan and Bihar. In Rajasthan mungbean is grown in 852297 hectares with annual production of 135510tonnes and productivity of $272 \mathrm{~kg} / \mathrm{ha}$ (Anonymous, 2006). In present oil seed crops form the main source of energy for major portion of Indian population due to less availability of animal fat and its ill effects on heart as it enhances the low density Lipoprotein level of cholesterol. Oil seeds form the largest agricultural commodity after cereals in India, sharing 13 per cent of the country's gross cropped area, 3 per cent of gross national product, 7 per cent of the world's production and 10 per cent of world's edible oil consumption (Anonymous, 2007). If one compares the average of productivity of castor and mungbean with its yield potential, one finds a big gap between these two figures and main reason being its poor nourishment. The crops are generally assigned to marginal and submarginal lands without or with little fertilization, particularly lacking in nitrogen and sulphur. Thus, it offers a great scope for increasing its productivity through sound crop husbandry and good agro techniques.

Research work done in different parts of the country indicate that application of sulphur to all crops and oil seeds and pulses in particular is highly profitable and seems essential for boosting the crop production. Sulphur plays an inevitable and imperative role in formation of amino acids viz., methionine, cystine and cysteine. It is also associated with synthesis of vitamins (biotine, thiamine), metabolism of carbohydrates, proteins and fats. Sulphur deficiency results in poor flowering, fruiting, and cupping of leaves, reddening of stems, petioles and stunted growth. These aspects of castor cultivation have received very little attention in light textured soils of this region and the inadequacy of experimental evidences regarding castor + mungbean intercropping systems and their sulphur levels, therefore, the present investigation entitled "Intercropping of mungbean [Vigna radiata (L.) Wilczek] with castor (Ricinus communis L.) under varying levels of sulphur" was carried out.

\section{Materials and Methods}

Experiment was conducted at the Agriculture Research Farm of the BHU, Varansi during 2012-2013. The experimental farm is located at $25^{\circ} 18 \mathrm{~N}$ latitude, $88^{\circ} 03 \mathrm{E}$ longitude at an altitude of $128.93 \mathrm{~m}$ above sea level in India. Varansi is located about $1600 \mathrm{~km}$ north of the Indian Ocean and has continental type of climate. Soil texture is sandy clay loam, high in organic matter $(0.44 \%)$, extractable phosphorus $\left(25.2 \mathrm{~kg}^{1}\right), \quad$ exchangeable potassium (216.20 $\left.\mathrm{kg}^{-1}\right)$, and alkaline $(\mathrm{pH}$ 7.35). Soil physio-chemical properties such as soil texture, International pipette method (Piper, 1950), organic matter (Walkely and Black method, 1934), Available nitrogen (kg/ha) Alkaline permanganate method 
(Subbiah and Asija, 1956) phosphorus, Olsen's method (Olsen et al., 1954) and Available potassium (kg/ha), Flame photometer method (Richards, 1954) were determined. Rainfall during the experimental period varied from $349.7 \mathrm{~mm}$ and $590.7 \mathrm{~mm}$ in 2012 and2013, respectively. Experimentation: $4 \mathrm{x}$ 4factors were conducted in a strip plot design with arrangement using three replications. The treatments consisted of four intercropping system in main plots [castor + mungbean (1: 1), castor + mungbean (1:2), castor + mungbean (2: 2 paired row) and castor + mungbean (2: 3 paired row) $]$ and four levels of sulphure in sub plots $(0,20,40$ and $60 \mathrm{~kg} \mathrm{~S} / \mathrm{ha}$ ). Castor variety, GCH-4 and mungbean variety, HUM-2 was used in the experiment. Net plot size of $4.5 \mathrm{~m}$ x $4.0 \mathrm{~m}$ was used. Sulphur will be applied through elemental sulphur as per treatment and A recommended dose of $60 \mathrm{~kg} \mathrm{~N} h a^{-1}$ and $40 \mathrm{~kg}$ $\mathrm{P}_{2} \mathrm{O}_{5}$ ha $^{-1}$ will be applied through DAP and urea.

Full dose of phosphorus through DAP and half dose of nitrogen through urea after adjusting with DAP will be applied as basal dose and remaining half dose of nitrogen will be top dressed at 40 DAS through urea. Data The produce from net plot area after thoroughly sun drying was weighed for recording biological yield. After threshing and winnowing the weight of seed of main and intercrop from each net plot area was recorded in $\mathrm{kg}$ plot $^{-1}$ and then converted into $\mathrm{kg} \mathrm{ha}^{-1}$. Stalk / straw yield $\left(\mathrm{kg} \mathrm{ha}^{-1}\right)$ was obtained by subtracting the seed yield from biological yield.

\section{Castor equivalent yield}

For the valid comparison of yield data, seed yield obtained for the components crops in different intercropping systems was converted into castor equivalent yield using prevailing rates of produce in the following expression

\section{Equivalent yield ( $\mathrm{Kg} \mathrm{ha}^{-1}$ )}

$=$ Seed yield of main crop $+\left(\frac{\text { Seed yield of intercrop } \mathrm{x} I}{\text { Price of main }}\right.$

Data was statistically analyzed according to Panse and Sukhatme.

\section{Results and Discussion}

\section{Yield attributes}

Yield and Yield attributes of castor were significantly influenced due to different intercropping system except test weight during 2012 and 2013.Higher values of these characters were recorded under Castor + Mungbean, 1:1 (Table 1). The castor + mungbean (1:1) intercropping system were at par with Castor + Moonbeam, 1:2 in all the parameters except seed yield and stalk yield during 2012.

Lowest yield and yield attributes were recorded with intercropping system of Castor + Mungbean, 2:3 which was at par Castor + Mungbean, 2:2 during 2012 and 2013. Sharma and Kulhari (2005) also reported that intercropping of castor with clusterbean, cowpea and mungbean were significantly reduced seed and stalks yields of castor as compared to $1: 1$ ratio scastor+mungbean. In different levels of sulphure, highest yield and yield parameters were recorded $S_{60}$ and it was on par with sulphure level of $\mathrm{S}_{40}$ as compared to other levels of sulphure during both the years respectively. Its might be due to favorable environment available to plants as also evident from higher dry matter accumulation under this system. Whereas, significantly higher seed and straw yields were obtained in castor + mungbean (1:2) intercropping system, which might reflect the effect of higher plant population in the system. 
Table.1 Yield and yield attributes of castor as influenced by different sulphure levels in intercropping system

Treatments

\section{A. Intercropping systems}

(i)Castor + Mungbean (1:1)

(ii) Castor +mungbean $(1: 2)$

(iii)Castor +mungbean (1:3)

(iv)Castor+mungbean(2:2 PR)

(v)Castor+mungbean (2:3 PR)

\section{SEm \pm \\ CD (P =0.05)}

B. Sulphur (kg/ha)

$\mathrm{S}_{0}$
$\mathrm{~S}_{20}$
$\mathrm{~S}_{40}$
$\mathrm{~S}_{60}$
$\mathbf{S E m} \pm$
$\mathbf{C D}(\mathbf{P}=\mathbf{0 . 0 5})$

\section{2}

Number of capsules primary racemes $^{-1}$
Seed yield (kg/ha)
Test Stalk berc

weight yield

(g)

$$
(\mathrm{kg} / \mathrm{ha})
$$
2013

\begin{tabular}{|l|l|l|l}
\hline ber of & Seed & Test & Stalk yield $(\mathrm{kg} / \mathrm{ha})$
\end{tabular} capsules yield (kg weight primary $\mathbf{h a}^{-1}$ ) racemes (g) 1 
Table.3 Effect of planting pattern and sulphur levels on castor equivalent yield and land equivalent ratio (LER)

Treatments

A. Intercropping systems

\section{Castor equivalent yield}

(kg/ha)

\begin{tabular}{|l|c|r|}
\hline (i) Castor + Mungbean (1:1) & 2893 & 1.81 \\
\hline (ii) Castor + mungbean (1:2) & 2658 & 1.67 \\
\hline (iii) Castor + mungbean (1:3) & 2459 & 1.55 \\
\hline (iv) Castor + mungbean (2:2 PR) & 2172 & 1.37 \\
\hline (v) Castor + mungbean (2:3 PR) & 2122 & 1.33 \\
\hline SEm \pm & $\mathbf{6 7 . 6 2}$ & $\mathbf{0 . 0 4}$ \\
\hline CD $(\mathrm{P}=0.05)$ & $\mathbf{2 2 0 . 5 3}$ & $\mathbf{0 . 1 2}$ \\
\hline
\end{tabular}

B. Sulphur (kg/ha)

(i) Control

(ii) 20

(iii) 40

(iv) 60

SEm \pm

$\mathrm{CD}(\mathrm{P}=0.05)$

\begin{tabular}{|c|c|}
\hline 2098 & 1.32 \\
\hline 2359 & 1.48 \\
\hline 2623 & 1.64 \\
\hline 2764 & 1.73 \\
\hline $\mathbf{4 9 . 7 4}$ & $\mathbf{0 . 0 2}$ \\
\hline $\mathbf{1 4 3 . 6 6}$ & $\mathbf{0 . 0 7}$ \\
\hline
\end{tabular}

\section{LER}

0.07

Yield and yield attributes of mungbean was significantly influenced due to different intercropping system during both the years (Table 2). Maximum mungbean parameters were recorded with intercropping system as castor + mungbea, 1:1 which was significantly at par with castor+ mungbean, 1:2 than remaining treatments during 2012 and 2013. mungbean $(1: 1)$ intercropping systems (Table 1). It might be due to favorable environment available to plants as also evident from higher dry matter accumulation under this system. Whereas, significantly higher seed and straw yields were obtained in castor + mungbean (1:2) intercropping system, which might reflect the effect of higher plant population in the system. Sulphure levels also influenced on yield and yield parameters of mungbean during both the years. Highest these parameters were recorded during 2013 as compared to 2012 with levels of $S_{60}$ followed by $S_{40}, S_{20}$ and $S_{0}$ during both the years respectively.

\section{Castor equivalent yield}

All the intercropping systems showed superiority to castor+mungbean in total productivity, as evident by castor equivalent yield (Table 3). The higher equivalent yield showed higher biomass production and efficient use of available growth resources under intercropping then other systems. The different behavior in crop equivalent yield was also on account of productivity of crops in intercropping systems and their relative market prices. Similar trend was observed earlier (Ganvir (2004) and Gupta Rathore, 1993) when castor intercropped with groundnut.

\section{References}

Anonymous, 2006. Paradigm shift in planning needed. The Hindu Survey of Indian Agriculture, pp. 63.

Anonymous, 2008. http//:www.agricoop. com. 
Anonymous, 2008. Wide array of improved varieties. The Hindu survey of Indian Agriculture, pp. 43

Ganvir MM, Jadhao PN, Raut RF, Shamkumar GR, Tagade UG (2004) Studies on castor based intercropping system under dry land conditions. Ann Pl Physiol18 : 55-57. 8.

Gopalan, G., Ramasastri, B.Y. and Balasubramanian, S.C. 1995.Nutritive value of Indian foods. ICAR, Hydrabad, 50,000, India.

Gupta IN, Rathore SS. 1993. Intercropping in castor (Ricinus communis) under dry land condition in Rajasthan. Ind $\mathbf{J}$ Agron38 : 182-186.

Olsen, B.C., Cole, C.V., Watenabe, F.S. and Dean, L.A. 1954. Estimation of available phosphorus in soil by extraction with sodium carbonate. USDA Circular No. 939, Pp. 19.

Panse VG, Sukhatme PV. 1985. Statistical methods for agricultural workers. 4th enlarged edn. ICAR, Publ, New Delhi. Anonymous, 2007. Hand book of Agriculture. ICAR, New Delhi, pp. 972-973.

Piper, C.S. 1950. Soil and plant analysis. The University of Adelaide, Australia: 286-287.

Richards, L.A. 1954. Diagnosis and improvement of saline, alkali soils. Handbook No. 60, Washington.

Subbiah, B.V. and Asija, G.L. 1956. A rapid procedure for the estimation of available nitrogen in soils. Current Sci. 25(8): 259-260.

Walkely, A. and Black, T.A. 1934. An examination of the method for the determination of soil organic matter and a proposed modification of the chromic acid titration method. Soil Sci. 37: 29-38.

\section{How to cite this article:}

Ghilotia, Y.K., R.N. Meena, R.K. Singh, Ajeet Singh and Kailash Verma. 2018. Effect of Sulphur Levels on Yield and Yield Attributes in Intercropping System of Castor along with Mungbean. Int.J.Curr.Microbiol.App.Sci. 7(07): 291-296.

doi: https://doi.org/10.20546/ijcmas.2018.707.035 